\title{
\begin{tabular}{lllllllllllllll}
$\mathbf{S}$ & $\mathbf{T}$ & $\mathbf{U}$ & $\mathbf{D}$ & $\mathbf{I}$ & $\mathbf{A}$ & $\mathbf{I}$ & $\mathbf{R}$ & $\mathbf{O}$ & $\mathbf{Z}$ & $\mathbf{P}$ & $\mathbf{R}$ & $\mathbf{A}$ & $\mathbf{W}$ & $\mathbf{Y}$ \\
\hline
\end{tabular} \\ ROCZNIKI HUMANISTYCZNE \\ Tom LXVIII, zeszyt $10 \quad-\quad 2020$ \\ DOI: http://dx.doi.org/10.18290/rh206810-1
}

ANNA DĄBROWSKA

\section{SUCCESSFUL CLASSROOM MANAGEMENT \\ IN ENGLISH LANGUAGE INSTRUCTION}

\section{INTRODUCTION}

At present, teaching foreign languages to young learners seems to be one of the key important educational issues for European school authorities, policy makers, parents and educators. Primary students begin to learn their first compulsory foreign language (most frequently English) earlier than in the past, between 6 and 7 years of age, with the increase by $18.7 \%$ of English beginners since 2005, reaching 79.4\% in 2017 (European Commission 13). Unfortunately, most problems teachers have to deal with have their roots in the lack of understanding of developmental dissimilarities between children and teenagers, and the lack of appropriate classroom management skills. The differences of each age group are based not only on conceptual and cognitive levels, but also on social and emotional ones (Komorowska 38). In the literature, the term 'young learners' generally pertains to a wide age range. Adopting the typology offered by Slattery and Willis (4), young learners (YLs) are defined as children between 7-12 years old, while very young learners (VYLs) are those under 7 years old. For some researchers, the period of young pupils covers 4-14 years of age, which is usually divided

Anna DĄBrowska, PhD - Maria Curie-Skłodowska University in Lublin, Institute of Modern Languages, Department of Applied Linguistics; e-mail: adabrowska.edu@gmail.com. ORCID: https://orcid.org/0000-0001-7170-4070.

Dr Anna DąiBrowska - Uniwersytet Marii Curie-Skłodowskiej, Instytut Neofilologii, Katedra Lingwistyki Stosowanej; e-mail: adabrowska.edu@gmail.com. ORCID: https://orcid.org/00000001-7170-4070. 
into three phases: (i) the kindergarten and reception level; (ii) early primary school years; and (iii) late primary school years (Singleton; Doff; Brown). Komorowska (32), in turn, distinguishes four basic age groups, namely, 4/5-7 years old, i.e. preschool and kindergarten groups including the first grade; 7/810/11 years old, i.e. early school groups; $12 / 13-15 / 16$ years old, i.e. older children; and 16/17-18/19 years old, i.e. intellectually mature youth groups.

In this light, the aim of the article is to share the most pivotal ideas concerning successful classroom management in teaching English to young learners. The emphasis is put on the need to adjust classroom organization and teaching techniques to young students, aged 7-12, which are mostly different from those offered to teenagers. Even though the focus in this paper is given to English, the issues discussed here can apply to other foreign languages as well. The article comprises four sections, that is: (1) introductory remarks and the aim of the paper being specified; (2) the theoretical background, in which two theories most useful for language instruction are explained, i.e. Critical Period Hypothesis and Piaget's Theory of Cognitive Development; (3) classroom management with teaching techniques adjusted to young learners, seen as the key factor of efficient English instruction; and (4) conclusion, in which all the main points are summarised.

\section{THE THEORETICAL BACKGROUND FOR ENGLISH INSTRUCTION OF CHILDREN}

Among numerous theories which offer essential reasons in favour of an early stage English instruction, there are two theories worth mentioning for the purpose of this paper, namely (i) Critical Period Hypothesis; and (ii) Piaget's Theory of Cognitive Development.

The Critical Period Hypothesis, initially proposed by Wilder Penfield and Lamar Roberts, refers generally to the first language acquisition; however, it is also commonly extended to the second language acquisition. The theory introduces an early stage of children's biological age as an ideal time frame to acquire a foreign language and achieve the native-like fluency (Gilzow 5). The period in which the human brain is most prepared to receive input and acquire a particular language is called the critical period. This phase of language acquisition coincides with lateralization process, i.e. lateral dominance by which the apparent specialization of the left hemisphere for language takes place. Singleton claims that not only the biological age but, 
more importantly, an adequate early-stage language input, a linguistically rich environment and sufficient motivation are the crucial factors which enable young pupils to achieve the full command of a language. Contrary to the $\mathrm{CPH}$ assumptions, Birdsong states that ultimate attainment is still possible among older learners, as proved by more than 20 studies that have reported the rate of nativelikeness among late L2 learners.

Furthermore, also Jean Piaget's Theory of Cognitive Development (1936) to language teaching is found useful for foreign language instruction in primary schools. Piaget postulates four stages of cognitive development, i.e. sensorimotor stage (up to age 2), pre-operational stage (age 2 to age 7), concrete operational stage (age 7 to age 11), and formal operational stage (from 11 to adolescence and adulthood). Following the implications of Piaget's theory, teachers should not instruct some issues, e.g. problem-solving tasks, until learners reach the proper stage of their cognitive development. Pupils, in turn, need to be active to acquire the essential knowledge (Piaget, "The role"; Szpotowicz and Szulc-Kurpaska).

Briefly speaking, the basic tenets of the above-mentioned theories may work as the guidelines for contemporary educators of primary school to improve their teaching skills.

\section{CLASSROOM MANAGEMENT STRATEGIES IN ENGLISH INSTRUCTION TO YOUNG LEARNERS}

The success of foreign language instruction in primary schools is reliant on a lot of factors. Whether teaching English brings results or not is primarily contingent on how the language teaching process is organized and how teachers manage to master various methods of teaching, fitted to young pupils and their learning capacities.

Classroom management is an umbrella term to cover a wide variety of skills and techniques used by the teacher to keep learners organized, concentrated, on task, well-behaved, and productive during the school day (Brophy 17). Martin and his colleagues (44) emphasize here the importance of antecedents of teacher action that guide classroom activity. However, for the purpose of this paper, I adopt Evertson and Weinstein's (4) definition of the term. Thus, classroom management refers to techniques and strategies ${ }^{1}$

\footnotetext{
${ }^{1}$ As elucidated by Larsen-Freeman (1), the term 'techniques' refers to actions of a teacher in a classroom, 'method' means a coherent set of links between the actions and the thoughts that
} 
a teacher uses to maintain control in the classroom, and the process by which the teacher and school build and maintain appropriate behaviour of students in the classroom. To be precise, classroom management entails "essential teaching skill" (Henley 4), comprising all the aspects that the teacher applies in order to facilitate and improve students' learning. These include: behaviour (a positive and encouraging attitude, joyful facial expressions, statements, respectful treatment of students, etc.), environment (a greeting, welllit classroom with intellectually motivating learning materials), expectations (the work the teacher expects students to do and the agreements that the teacher makes with students), materials (all the resources, texts, equipment, etc.), and activities (teachers' learning experiences designed to passionately engage students' attention and interests).

The objective of implementing classroom management strategies is to develop prosocial behaviour among learners, minimize the behaviour that impedes learning, and increase their educational engagement (Baer 15-16). On the other hand, unclear expectations, weakly designed lessons and unexciting learning materials can lead to lack of students' interest, increased behavioural problems, disorganized classes, chaos and stress, which, consequently, create an unsatisfactory environment both for the teacher and learners themselves. Based on the experience of many contemporary teaching experts (cited below), four basic classroom management strategies, listed in (1), seem to be the most crucial ones to master classroom organization and create a quality learning environment for young learners.

(1) Four basic classroom management strategies for young learners

a) Entry rules and daily classroom routine

b) Class curriculum

c) Transition routine

d) Teaching materials and techniques.

The first classroom management strategy entails establishing a list of entry rules and daily classroom routine, which, if taught openly and consistently, will "provide children with consistency, confidence, security, trust, and a sense of safety because the routines allow them to identify patterns

underlie the actions, and the thoughts are the 'principles'. Brown defines a 'strategy' as "any number of specific methods or techniques for approaching a problem or task; modes of operation for achieving a particular end; planned designs for controlling and manipulating certain information" (390). In short, while a teaching strategy is the plan of teaching activities to be undertaken, a teaching technique is the individual teachers' unique way of applying a strategy in the teaching and learning process. 
that help them predict what is going to happen next" (Salmon 132). The teacher, indeed, should make his/her main concern to spend extra time discussing the classroom behaviour code with the pupils. The rules should be positive, mutually fair and practical. Besides, the classroom expectations should be well understood, measurable, explained by examples, and based on context, such as the group setting or size. Instructions that are either too easy or too difficult can result in an off-task behaviour. Also, too many rules and expectations will make young students feel confused and overwhelmed. Therefore, the entry rules and daily routine list will start with primary students' entrance to the classroom and preparing learning materials. Making seat arrangements, moving in the classroom, following the colour-code, working individually, in pairs or teams, doing a brief physical warm-up, passing in assignments, and leaving the classroom. As Cameron points out, "we can see how classroom routines, which happen every day may provide opportunities for language development" (10). Certainly, when displayed in a visible place in the classroom, the rules and daily routine list will be easier to be re-taught throughout the year. The teacher should expect children to do what they are asked in a kind but consistent manner, making sure the instructions are followed. Everyone is supposed to begin the class feeling confident and attentive. This strategy can avoid chaos and wasted time at the beginning of a class period (Watson and DiCarlo 89). Nonetheless, if there is little or no response to the entry rules, learners, especially with some learning problems, may need a stronger or personalised intervention. In fact, applying intensive socio-emotional interventions for pupils with behaviour difficulties usually contributes to equipping students with the competencies, skills and motivation they need in order to behave properly (Durlak et al. 417-418). This also leads to enhancing classroom management effectively.

The second classroom management strategy that should facilitate student engagement refers to class curriculum. Incorporating students' interest into the course makes them become more devoted to what they are learning (Kern and Clemens). The love of learning may be fostered by creating lesson plans, appealing to students and suiting their young age and primary level of knowledge. Accordingly, the teacher plays the role of helping pupils develop into lifelong learners. Significantly, the course curriculum and each lesson plan are also required to be well-adjusted to the needs of students with learning problems and disorders (Komorowska 52-53).

A transition routine is the third essential classroom management strategy to be established. When changing an activity, the teacher may use a rattle in- 
stead of raising his/her voice to attract students' attention. Consequently, the signal of a rattle will get recognizable to the learners. Lemov (6) calls this kind of technique 'tight transition', promising that it helps to maximize time for learning, by reducing disorder and delay that frequently occur in transitions between activities. Indeed, as confirmed by Banerjee and Horn (4), a tremendous amount of time (from $20 \%$ to $23 \%$ of the time) is wasted on transitions, while moving from activity to activity. Also by using brief instructions (such as 'reading time', 'do it now' or 'now could you please'), the teacher draws pupils' interest quicker and gets them settled, much more concentrated, involved, and productive. In addition, the teacher may improve the speed of a lesson by means of a stopwatch and short commands, e.g. 'Now let's do this in 10 seconds', or by using nonverbal signals, such as hand movements, eye contact or gestures. This will make the class and communication more vivid and save the precious learning time (Lemov 6).

The forth step to improve classroom management and effectiveness, and the last one mentioned in this article, concerns teaching techniques, listed in (2), which should be adjusted to the characteristics of young students (Komorowska 38).

(2) Teaching techniques adjusted to the characteristics of young learners (aged 7-12)

a) The period between six and ten / eleven years of age is very good to start foreign language learning, since children of this age learn it like a native language and language functions are not yet permanently assigned to one area of the brain. At this age, learning is not conscious and intended, but intuitive; whereas, the right cerebral hemisphere is responsible for learning by means of gestures, facial expressions, emotions, sensations received in the form of colour, image and sound, as well as using ready phrases (Szpotowicz 124). Only in adolescence does the left hemisphere take over the functions responsible for using the language, and the so-called lateralization process ends.

Accordingly, knowledge and language are "acquired through continuous exposure and use" (Halliwell 5). Unlike Piaget (Science of Education), Vygotsky (Thought and Language) gives a much greater priority to social interaction in the intellectual development of a child. The adult's role is very important in a child's learning process because "with the help of adults, children can do and understand much more than they can on their own" (Cameron 6). Similar to Vygotsky, Bruner underlines the importance of the language in a child's cognitive development. Sup- 
porting a child in carrying out an activity has been labelled 'scaffolding', in which the teacher pushes the learner to guide his language learning through finely-tuned talk (Cameron 8).

b) As claimed by Bruner, children learn by repetition and routine, since "the repeated language allows the child to predict what is coming and thus to join in, verbally or non-verbally" (Cameron 10). Thus, the teacher may easily ask them to repeat mechanical drills and engage them into imitating activities (mime, gestures and acting). Children are comfortable with routines and enjoy rhythmic and repetitive language more than adults do (Slattery and Willis 4). Children's learning and having fun are founded on imitation more than on their awareness of language itself. Imitation may be well used to introduce new vocabulary, which leads to correct articulation, intonation of sounds and their memorization. Indeed, the flexible larynx young learners have and their most effective brain create a great opportunity for language acquisition and nearly ideal imitation of sounds (Komorowska 128).

c) Children have limited writing and reading skills (Cameron 67). Hence, the teacher should apply more listening and communication drills, especially in students' early primary years. Children are drawing on the paralinguistic features of communication such as "intonation, gesture, facial expression, actions" (Halliwell 3). Importantly, the teacher should let the children play with the language, talk to one another or to themselves as often as possible, and tell stories (Komorowska 30, 41, 113). Besides, in order to extend children's range of English words and phrases, the teacher should work beyond textbook, include learners' choice, and use supplementary learning through illustrated books, video stories, songs, and rhymes (Cameron 91).

d) A child is extremely active and enthusiastic while being amused and involved, and enjoys learning through playing, fun activities and games, especially in teams. His/her preference for participating in plays and role-taking in an imaginative set-up results from the fact that he can think and act "as though he were a head taller than himself" (Vygotsky, Mind in Society 102). Piaget (Science of Education) elucidates that such a preference for play can be explained in terms of children's incomplete overall knowledge of the physical world. Both Vygotsky and Piaget consider play a key aspect of learning and cognitive development, through an active exploration and experiencing the reality themselves. Likewise, Halliwell (5) confirms that play constructs a non-threatening, secure context in which children can experiment with new activities. 
e) Children have a short attention span, and they need a lot of physical movement. Hence, teaching techniques should be varied, language activities should involve movement and absorb young learners' senses. The number of short exercises needs to be increased to improve pace and diversity, and thus keep children's attention (Komorowska 76). For Cameron, if children are to be kept attentive and mentally active, "the teacher must be alert and adaptive to their responses to tasks, adjusting activities and exploiting language learning opportunities that arise on the spot" (111). Teachers can adapt lessons through the use of stir and settle activities (Halliwell 20). When a teacher finds that young learners' attention begins to wander, the activity needs to be switched to a more vivid one.

f) Children construct knowledge from actively interacting with the physical environment in developmental stages. Taking into account Piaget's (Science of Education) hypothesis, children from age 7 to age 11, while being in their concrete operational stage of development, are said to learn through their own individual actions and exploration of the real world. Piaget's main concern is "how young children act in the world around them, and how this influences their mental development" (Cameron 2). Following Piaget's (Science of Education) rules of 'assimilating new experiences' and 'accommodating to fit the new experience,' a child can be called an 'active thinker' who constructs their own knowledge from working with objects and by solving problems around him (Cameron 2-3). Indeed, children are imaginative but prefer learning the language through concrete (visual) things rather than abstract ones. As underlined by Komorowska (21), the teacher should use real objects, visuals, board drawings and pictures to stimulate students' thinking, help them make connotations and memorise new vocabulary. The teacher needs to use physical activities and school surroundings, inserting culture-related elements to make learners feel more convenient and familiarised.

g) Young learners become more logical and analytical in their thinking processes. At the age of 7-9 they get more aware about the language, recognising its patterns and asking frequent what/why questions. The teacher should be patient, since children have different experience and talents for language learning. He/she should treat the students individually and fair, without favouring more linguistically talented learners (Szpotowicz and Szulc-Kurpaska 75). When given a chance to work 
alone or in small teams, and being monitored and carefully supported, these learners will grow rapidly, and feel appreciative to present their improving abilities. For young students, the praising feedback (Good, Excellent, Well done!), rewards and surprise activities are reinforcing. This technique increases a positive behaviour in students, and establishes a group culture in which learning accomplishments and positive actions are socially valued and rewarded (Komorowska 37).

h) In their late primary school years (11-13), students are usually challenged with an examination component in mainstream schooling. They will take their learning more seriously, absorbing and retaining information (Komorowska 113). Their intellectual and social skills will become more pronounced, which commonly results from longer attention spans. Hence, they can undertake individually more absorbing activities even for longer periods, participate in a larger range of classroom activities and topics, and search for answers for more intriguing issues and complex questions. Nonetheless, these older primary learners get more sensitive to a peer group positive reaction; therefore, they may feel fearful of ridicule, afraid of speaking in front of the group, and become more introverted (Komorowska 77). For that reason, teachers play a particularly important role in understanding the individual, being patient and flexible, providing proper support and helping learners bring gradually to their full potential at this level.

\section{CONCLUDING REMARKS}

In order to succeed in teaching English to young learners, the teacher is required to be not only a highly trained professional with the knowledge of the language but also specialized in classroom management skills that have been deliberated in this paper.

To conclude, making an attempt to introduce classroom management strategies into one's teaching practice, first, the objectives, the contents, and the syllabus of (pre-)primary English teaching should be well-discussed and attuned to the overall curriculum of primary education. Second, the educator is expected to gain sufficient knowledge concerning the basics of different age-related stages of children's development, and characteristics of young learners, both on linguistic, intellectual, psychological and emotional levels. Further, it is the teacher's natural abilities and pedagogical skills which lead 
to the efficient English instruction. Hence, tutors should be understanding and patient since children have a short attention span. At this educational stage, children should not be expected systematic language progression, but rather building motivation for language learning and the foundations for later systematic work with language (Komorowska 37).

To overcome boredom during classes, teachers are required to give their pupils a variety of tasks, depending on the age, characteristics and learning disorders of primary students. Trying to understand the strengths and needs of young students, the teacher can better plan activities that allow for a cohesive and collaborative classroom. In other words, effective teachers usually display strong classroom-management skills, while inexperienced or less effective instructors form a disorganised classroom with learners who neither work nor pay attention. Indeed, implementing classroom management strategies creates a positive learning environment for students of English and helps them master successfully the materials presented. The decision whether the challenge of teaching will bear successful fruit depends mostly on teachers themselves (Brzeziński 166; Komorowska 86). Young learners, in turn, can be a real pleasure to teach because they do not feel stressed by their studies, but approach naturally whatever they are taught, usually with youthful innocence.

\section{BIBLOGRAPHY}

Baer, George G. "Preventative and classroom-based strategies." Handbook of Classroom Management, edited by Edmund T. Emmer and Edward J. Sabornie. 2nd ed., Taylor and Francis Group, 2015, pp. 15-39.

Banerjee, Rashida, and Eva Horn. "Supporting Classroom Transitions Between Daily Routines: Strategies and Tips." Young Exceptional Children, vol. 16, no. 2, 2013, pp. 3-14.

Birdsong, David. "Age and second language acquisition and processing: a selective overview." Language Learning, vol. 56, 2006, pp. 9-49.

Brophy, Jere. "History of research on classroom management." Handbook of Classroom Management: Research, Practice, and Contemporary Issues, edited by Carolyn M. Evertson and Carol S. Weinstein, Lawrence Erlbaum Associates, 2006, pp. 17-43.

Brown, Douglas H. Principles of Language Learning and Teaching. 5th ed., Pearson, 2007.

Bruner, Jerome. Child's Talk: Learning to Use Language. Oxford UP, 1983.

Brzeziński, Jerzy. O nauczaniu języków obcych dzieci [About Teaching Foreign Languages to Children]. WSiP, 1987.

Cameron, Lynn. Teaching Languages to Young Learners. Cambridge UP, 2001.

Doff, Adrian. Teach English: A Training Course for Teachers. 14th ed., Cambridge UP, 2000. 
Durlak, Joseph A., Roger P. Weissberg, Allison Dymnicki, Rebecca Taylor, and Kriston Schellinger. "The impact of enhancing students' social and emotional learning: A meta-analysis of school-based universal interventions." Child Development, vol. 82, 2011, pp. 405-432.

European Commission/EACEA/Eurydice. Key Data on Teaching Languages at School in Europe - 2017 Edition. Eurydice Report. Publications Office of the European Union, 2017.

Evertson, Carolyn M., and Carol S. Weinstein, editors. Handbook of Classroom Management: Research, Practice, and Contemporary Issues. Erlbaum, 2006.

Gilzow, Douglas F. Model Early Foreign Language Programs: Key Elements. Center for Applied Linguistics, 2002.

Halliwell, Susan. Teaching English in the Primary Classroom. Longman, 1992.

Henley, Martin. Classroom Management: A Proactive Approach. $2^{\text {nd }}$ ed., Pearson, 2010.

Kern, Laurence, and Nathan H. Clemens. "Antecedent strategies to promote appropriate classroom behavior." Psychology in the Schools, vol. 44, 2007, pp. 65-75.

Komorowska, Hanna. Metodyka nauczania języków obcych [The Methodology of Teaching Foreign Languages]. Fraszka Edukacyjna, 2005.

Larsen-Freeman, Diane. Techniques and Principles in Language Teaching. 3rd ed., Oxford UP, 2011.

Lemov, Doug. Teach Like a Champion: 49 Techniques That Put Students on the Path to College. Jossey-Bass, 2010.

Martin, Nancy K., Nancy J. Schafer, Sandee McClowry, Tim Mainhard, and Theo Wubbels. "Expanding the definition of classroom management: Recurring themes and new conceptualizations." Journal of Classroom Interaction, vol. 51, no. 1, 2016, pp, 36-45.

Piaget, Jean. Science of Education and the Psychology of the Child. Translated by Derek Coltman. Orion Press, 1970.

Piaget, Jean. "The role of action in the development of thinking." Knowledge and Development, edited by Willis F. Overton and Jeanette McCarthy, Gallagher, 1977, pp. 17-42.

Salmon, Angela K. "Engaging young children in thinking routines." Childhood Education, vol. 86, no. 3, 2010, pp. 132-137.

Singleton, David. The Age Factor in Second Language Acquisition: A Critical Look at the Critical Period Hypothesis. Multilingual Matters Ltd, 1995.

Slattery, Mary, and Jane Willis. English for Primary Teachers: A Handbook of Activities \& Classroom Language. Oxford UP, 2001.

Szpotowicz, Magdalena, and Małgorzata Szulc-Kurpaska. Teaching English to Young Learners. Wydawnictwo Naukowe PWN, 2012.

Vygotsky, Lev S. Thought and Language. MIT Press, 1962.

Vygotsky, Lev S. Mind in Society. Harvard UP, 1978.

Watson, Kamille J., and Cynthia F. DiCarlo. "Increasing Completion of Classroom Routines Through the Use of Picture Activity Schedules." Early Childhood Education Journal, vol. 44, no. 2, 2016, pp. 89-96. 


\section{UMIEJĘTNE ZARZĄDZANIE KLASĄ W PROCESIE NAUCZANIA JĘZYKA ANGIELSKIEGO}

\section{Streszczenie}

Artykuł ma na celu podkreślić znaczenie dostosowania organizacji klasy i technik nauczania języka angielskiego do uczniów z różnych grup wiekowych szkoły podstawowej. Aby skutecznie wdrożyć to rozwiązanie, nauczyciel powinien być świadomy różnic rozwojowych dla każdego wieku oraz zdobyć umiejętność zarządzania klasą. Kluczowe znaczenie ma również fachowa wiedza teoretyczna związana z wczesnym nauczaniem języka angielskiego (np. hipoteza okresu krytycznego oraz teoria rozwoju poznawczego według Piageta) i zastosowanie jej w praktyce nauczycielskiej. Aplikując rozwiązania omówione w tym artykule, nauczyciel ma szansę odnieść sukces w nauczaniu języków.

Słowa kluczowe: edukacja; język obcy; uczniowie szkół podstawowych; zarządzanie klasą.

\section{SUCCESSFUL CLASSROOM MANAGEMENT IN ENGLISH LANGUAGE INSTRUCTION}

\section{S u m m a ry}

The aim of this article is to emphasise the significance of adjusting classroom organisation and teaching techniques to primary students. To perform this task effectively, the teacher needs to be familiarised with the characteristics of a child's development and appropriate management skills. This paper is based on two theories related to early stage English instruction: (i) the Critical Period Hypothesis, and (ii) Piaget's Theory of Cognitive Development. Applying this theoretical background knowledge to teaching practice would make the teacher more likely to succeed in language teaching.

Key words: education; foreign language; primary students; classroom management. 